\title{
Marketing Strategy of Higher Education Institutions
}

\author{
Kalenskaya N.V. \\ Kazan Federal University, Institute of Management, Economics and Finance, Kazan, 420008, Russia
}

\section{Doi:10.5901/mjss.2015.v6n1s3p146}

\begin{abstract}
The article reveals the essence of the formation of the university's marketing strategy allows us to adapt to the requirements of the market. Also in the article shows the results of the analysis of motives in choosing profession and the university. Also allow conclusions to strengthen the power of the brand of the university for prospective students
\end{abstract}

Keywords: marketing strategy, brand, of the university, image of university

\section{Introduction}

Marketing approach to the management of educational services is particularly relevant because it allows adapt of the learning process to the needs of the market. According to estimates for the normal functioning of the market for goods and services in Russia requires almost 0.5 million of professionals in the field of marketing.

In the field of educational services marketing helps to predicts the changes of the market and adapt students to the needs of buyers (employers).

Required aspect of competitiveness becomes universities focusing on the global education standards, improving the quality, relevance and practical relevance of educational products and services. Advanced technologies are being introduced in the process of learning, curricula and standards are directed to the needs of the employed market and to the level of competences. During the development of the strategy of the university are accounted different needs, opportunities and motivation of staff. All this contributes to active implementation of marketing tools in the activity of universities.

In the formation of the brand of university the demand for graduates shows the degree of loyalty to this institution. Motivations of students are of great importance, as they choose one or the other institution or particular profession. It is the student's choice of a benchmark relevance of the university and the future profession.

\section{Theory}

Marketing activities of the university primarily focused on the needs of the market then develops requirements for quality educational services. The quality of education is a necessary condition for the competitiveness of the university in terms of international integration, high domestic competition. The quality of education depends on the teaching competence and experience.

Marketing education could be defined as a system of adaptation to operate the market activities directed to satisfy of social needs with the efficiency of the educational institution.

In this way, marketing education is the ideology of strategy and tactics of the institution at which the implementation of the system solution to the problems of the state on promising research areas and the satisfaction of highly qualified personnel. This increases the reputation (image) of the institution and leads to its prosperity.

Study of the principles of marketing allows to the Institutes to function in conditions of uncertainty of the educational environment. Marketing as a method of assessment and prediction of the environment allows the organization to more fully assess market opportunities, needs and demands of customers, taking into account their capacity to identify the most effective model of market behavior. The mechanism of formation of the marketing strategy of the university is shown in Pic. 1.

For the implementation of the marketing activities of educational institutions use a variety of tools that form the complex of marketing to influence the demand for their services. Marketing mix is one of the basic concepts of modern marketing. Under the "complex marketing" means a series of uncontrollable marketing variables that the firm uses in an effort to induce the desired responses from the target market. 


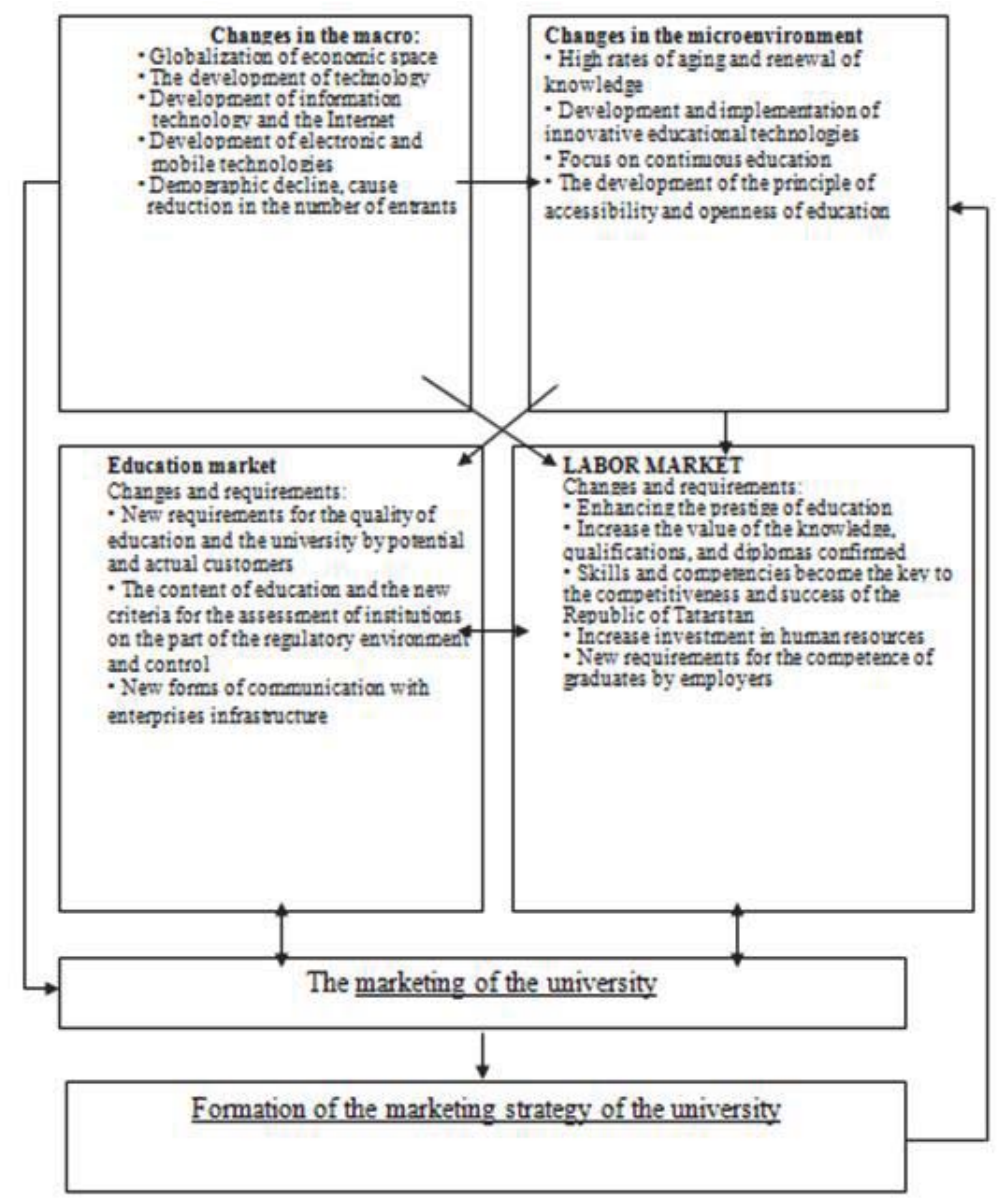

Pic. 1. Formation of the marketing strategy of the university

\section{Results}

As shown, the beginning of a marketing strategy laid into the motives of the students. In the formation of the brand of the university we must answer questions from students:

1. What is the purpose of the entrant to enter higher education institution?

2. What was the cause of the need for education (which external and internal stimulus)?

3. In what educational services is urgently required in the market, what educational services are most attractive?

Answering to these questions university can build an effective marketing strategy in its positioning in the market of educational services.

After realizing the need for education, begins a phase of active search for information on educational institutions and the range of services they provide. At this stage the search for efficiency and completeness of the information, educational institutions should consider the following points:

- What kind of information interests of potential customers? From what sources consumers receive information about educational institutions and their services?

- What sources are most trusted by consumers?

According to our estimates, the main sources of information for consumers on educational institutions parent's opinion follow $45 \%$, the opinion of friends - $40 \%$ of respondents and specialized literature (manuals, brochures, etc.) - for $15 \%$ of examined people.

Thus, we can conclude that the greatest influence in the choice of the university have reference groups than the specialized literature and specified-events.

However, the results of the survey among students of 2-4 courses in "Marketing" (108 students), the main motive of getting higher education are presented in Table 1. 
Table 1. Motivation for higher education

\begin{tabular}{|c|l|c|}
\hline № п.п. & Possible reasons for the choice & The importance of the motives on the 5-degree scale \\
\hline 1 & Getting good profession which provides good salary & 4,8 \\
\hline 2 & Opportunity to make a good career & 4,5 \\
\hline 3 & The image of the university and faculty & 4,3 \\
\hline 4 & Thirst for the knowledge and curiosity & 4,0 \\
\hline 5 & It is easier to find a job in their chosen specialty & 3,8 \\
\hline 6 & Schedule of future work & 3,7 \\
\hline 7 & Effect of activities before university & 3.6 \\
\hline
\end{tabular}

-When you start collecting the necessary information? For what period of the year is the active search? Research shows that active and conscious search for information on educational institutions begins in 9-11 class. However, about 1/3 of high school graduates at the beginning of the year have not yet decided on a specialty and educational institution.

Thus, the most active search for information comes for the last year before the entrance exams. This time of universities must be used to attract potential students, holding the events like open days, Olympiads, conducting classes for teachers of universities, Schools etc.

Finally, educational institutions must take into account the opinion of others who is the most influential in the choice of educational institution. Point that domestic communication way is the most trusted for potential consumers, so the educational institution need to work not only with prospective students, but also their parents and teachers.

Then implements analysis of the available information, the assessment of the available options for education and selection of the best benefits. Based on the most important criteria for evaluating the attractiveness of an educational institution a potential consumer compares the alternatives of those universities, which information is sufficient and complete. Therefore, the more information about various aspects of the educational institution and its services the higher the percentage of consumers for whom this information is available, the more chance of getting into the educational institution and become one of the alternatives for being selected for entering.

Selected options are measured by the consumer on the criteria that consumers are the most significant. This may be the price of educational services, the form of training, prestige of the university, its location, qualification of the teaching staff, the ability to obtain additional services (to obtain a diploma of an interpreter), the availability of hostels etc.

For specialists in marketing field of university it is important to know which of these criteria are selected the best alternative in each market segment.

Thus, analyzing the behavior of consumers at decision about choosing the university, it is important to know the following:

1. What educational institutions, educational and related activities are considered by consumers as alternatives?

2. Does this university in the top 50 universities in Russia or the top 100 of the world or not?

3. Which criteria are used by consumers to compare available options, and which criteria are most important for each consumer segment?

Answers to these questions allows for the institution to develop an effective marketing strategy to promote their services, focusing on the characteristics of the educational institution, which are regarded by buyers as decisive in choosing the best option.

As shown by our analysis - two markets form the marketing strategy of the university. This market is of users of educational services market and employer. The mechanism is shown in Pic. 2 


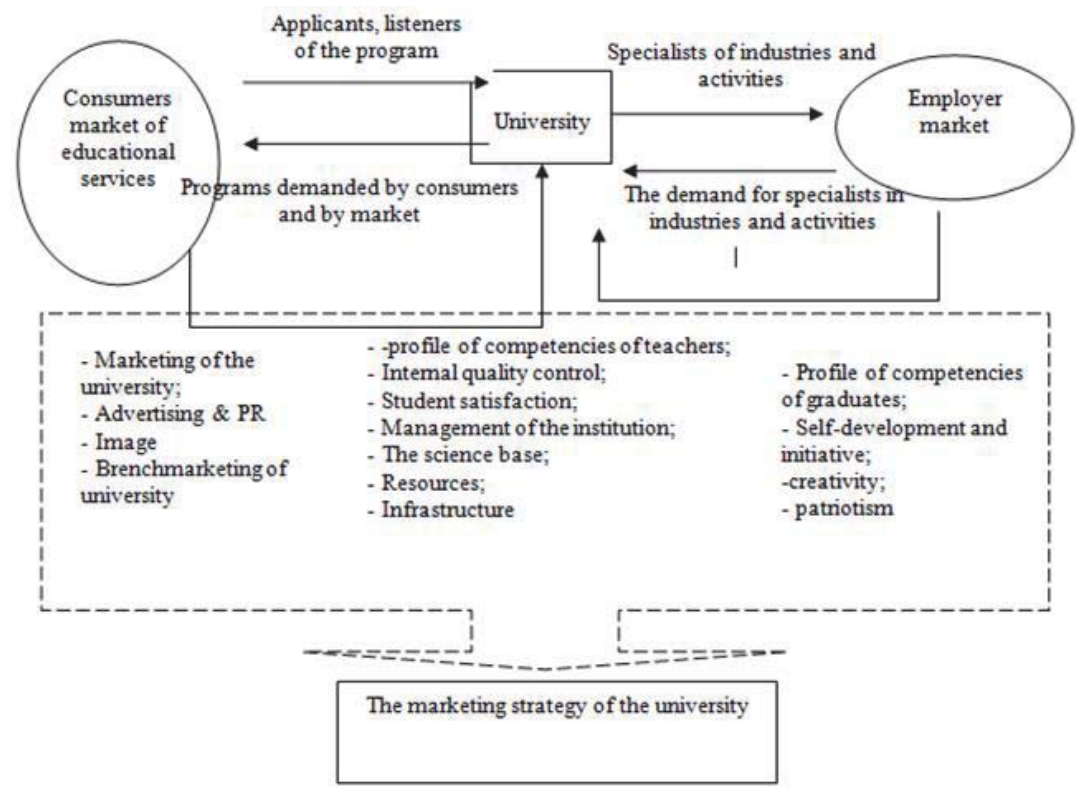

Pic. 2. Marketing support of the university

In our opinion, the goods in the complex educational marketing is an educational program, which organization offers to consumers and markets. At the same time it is necessary to form the basic direction of marketing strategies.

The price of education is the main element in combination with the marketing for educational institutions, where the basis for financing is payment for services by consumers. Correct positioning of the university and the educational program from the financial point of services which provided as "public", "elite" or "with the best combination of quality and price" is an important component of the marketing strategy of the university.

Buyer of educational products would be ready to pay a higher price, or continue to purchase products at the same price in the economic crisis, if the manufacturer can demonstrate "added value": additional services, improved performance of educational programs that distinguish them from the competitors, additional features as quality of service, utmost care staff of the university, etc. The tools of distribution channels and promotion must be used while implementing the marketing strategy of the university. Analysis of the following areas is necessary to carry:

1. The real state of the educational institutions in the market and among competitors;

2. Develop of strategies and tactics of educational services;

3. Quick decision-making at the conclusion of economic agreements, cooperation agreements.

A successful marketing strategy of educational institution depends on a well-coordinated action unit, which form the internal environment of marketing. It includes:

- Resource providing of educational institution (its administrative, scientific and pedagogical, methodological, financial, logistical capacity, the internal culture of the enterprise);

- Organizational support (tools and systems management, planning and control);

- Information provides (marketing information system of educational institutions).

Following the concept of the marketing approach, all these elements of the internal environment must be tightly controlled by the organization to function as a unit, "thinking like a customer" with purpose to provide for the clients the educational services with high value.

The internal environment of educational institutions, in comparence with other areas of the economy has the most extensive and strong feedback from the external environment, as it forming a whole generation of specialists, which in its further work begins to determine the changes of the environment. On the other hand, education is more than any other sphere of activity, which are affected by the external environment.

On the basis of the analysis of internal and external environment of the university can be build a tree of goals of the university and the factors matrix of the internal environment. 


\section{Conclusions}

Study of the formation of a marketing strategy allows the university to make conclusions.

Identified the main steps in the process of quality assurance in the university system of marketing, they are: 1)

Formation of parameters of the quality of education in accordance with the requirements of the consumers of educational services, and taking into account the selection criteria of the institution customers; 2) Estimation of conditions of achievements identified parameters and their integration into the system of strategic marketing planning activities of the educational institution; 3) Adaptation of types and forms of educational services in accordance with the changing market trends and customer needs; 4) Planning of necessary resources, which provides suitability of work of universities to have high indicators of quality and to match to customer needs, and prediction of their volume with current market trends of educational services;

5) Formation of human resources of the university providing the required level of quality of education, including taking into account the predicted values of indicators.

The purpose of the university is to study consumers' needs and offer a wide range of educational programs at various levels, the introduction of integrated modular educational programs, which increases the value of marketing in the activities of the university. Introduction of innovative education technologies, electronic and mobile, significantly reduces the costs related to consumers, allowing more widely and quickly enter new markets. It gives possibilities to the implementation of the principles of marketing to a concentrated group of target consumers and global marketing at an exit on transnational markets. The multilevel and exclusivity educational product determines that adequate support in the process of delivery to the consumer that requires highly skilled personnel. Besides, the effectiveness of the educational activities of the university in modern conditions depends on the degree of involvement and coordination of staff in the process of identifying and satisfying needs. This is the basis of the marketing activities of the university.

\section{References}

Bagautdinova N.G., Gafurov I.R., Novenkova A.Z. The transformation of region's economic area governed by the development of industrial region // World Applied Sciences Journal, 25(7), 2013, 1113-1117.

Tiebout C. A Pure Theory of Local Expenditures. The Journal of Political Economy. - 1956. Vol.64.№5.-P. 416-424.

Auzan A.A. Insitutional Economy: new institutional economic theory. - M.: INFRA - M, 2007.- S. 56.

Bagautdinova Nailya, Gafurov Ilshat, Kalenskaya Nataliya, Novenkova Aida (2012). The Regional Development Strategy Based on Territorial Marketing (The Case of Russia). World Applied Sciences Journal 18 (Special Issue of Economics): 179-184.

Bagautdinova, N.G., Murtazina, G.R., Fazlieva, E.P., Naida, A.M. (2013). Improvement of the regional management system using the labor potential index. World Applied Sciences Journal, 27(1), 107-111.

Kramin, T. V., Ismagilova, G. N., \& Kramin, M. V. (2014). Assessment of Effect of Large Investment Projects on Development of Investment Potential of Regions of Russia as Exemplified by Universiade 2013 in Kazan1. Mediterranean Journal of Social Sciences, 5(18), 255.

Bagautdinova, N.G., Galeeva, G.T., Kundakchyan, R.M.(2013). Development of the corporate management system in the modern context. World Applied Sciences Journal, 27(13), 43-47.

Kramin, T. V., Safiullin, L. N., \& Timiryasova, A. V. (2014). Defining Priorities of Management of Investment Attractiveness of the Region and their Consideration in the Framework of Implementing Large Sports Events1. Mediterranean Journal of Social Sciences, 5(18), 275.

Ablaev I.M., Khovanskaya E.S. Essence and Economical Substance of Innovative Cluster in Territorially Localized Business System// Mediterranean Journal of Social Sciences.- Vol.5, No12, (2014)-pp.159 - 162.

Varlamova J.A., Larionova N.I. Economic behavior of households: cross-country comparison. Life Science Journal 2014; 11(6s): 409413.

Kramin, M. V., Safiullin, L. N., Kramin, T. V., \& Timiryasova, A. V. (2014). Drivers of economic growth and investment attractiveness of Russian regions. Life Science Journal, 11(6s).

I.Sh. Khasanov, Three-sector structure of the national economy of Russia // Asian Social Science, Volume 10, 2014, Pages 217-224.

Vakhitova T.M., Gadelshina L.A. Directions of the region transport infrastructure development in the context of its competitiveness // Mediterranean Journal of Social Sciences vol. 5 № 24, November 2014, pp. 313-316. 